\title{
三相式嫌気性メンブレンリアクターに おけるメタン生成細菌の活性について
}

\author{
油科 嘉 則* 長 谷 川 潤*
}

\section{Methane Production Activity of Methanogenic Bacteria in a Two-Phase Anaerobic Membrane Reactor}

\author{
Yoshinori YUSHINA* and Jun HASEGAWA* \\ Research \& Development Center, Chiyoda corporation, 3-13 Moriya-cho, Kanagawa-ku, Yokohama 221 Japan
}

\begin{abstract}
Specific methane production activities (SMPAs) of methanogenic bacteria attached on carriers in a pilot-scale two-phase anaerobic membrane reactor were investigated. In the process a membrane was placed between acidification and methane reactors. The plant treated continuously a soybean processing wastewater. Vial tests were conducted using six different substrates and bacteria grown in each fixed bed reactor. The test results are shown as follows;

1) Bacteria attached on the methane reactor carriers showed higher SMPAs than those of bacteria in the acidification reactor in case of using formate, acetate, propionate or butyrate as a substrate.

2) A SMPA of ethanol decomposition revealed an extremely high value concerning bacteria in the acidification reactor. It was assessed that metabolic groups of bacteria converting ethanol to methane played an important role in the acidification reactor.

3) In comparison with SMPAs of UASB granules in the literature, methane reactor bacteria had almost equal or higher SMPAs and demonstrated a similarity ot UASB granules cultured by a mixture of organic acids, Hence, the methanogenic consortia similar to those in UASB granules were estimated to be present on the carriers in the existing methane reactor.
\end{abstract}

Key words : methane fermentation, two-phase, membrane reactor, vial test, specific methane production activity

\section{1.はじめに}

メタン発酵プロセスの処理効率を向上させるため に，二相式メタン発酵法は研究開発されすでに実用化 されている。メタン発酵における基質分解過程は,一 般に酸生成過程とメタン生成過程の二つに分けられて きた。そして，各々の過程に関与する細菌を酸生成細 菌, メタン生成細菌と呼ぶ。二相式メタン発䣲装置に おいては両者の細菌が二槽内に各々独立して存在する
わけではなく，廃水中の有機物の組成および存在形態 によって種々の細菌が共生関係を維持していると考え られる。つまり工場廃水や都市下水等の嫌気性生物処 理においては異種の基質の分解ならびに固形物や高分 子有機物の可溶化と生物学的分解が逐時並行的に行わ れ，化学的組成が常に変化している。これらの変化す る基質の分解に関与する細菌は互いに競合関係や共生 関係を保ちつつ，酸発酵槽およびメタン発酵槽に生存 している1。

* 千代田化工建設㑣環境技術開発センター 


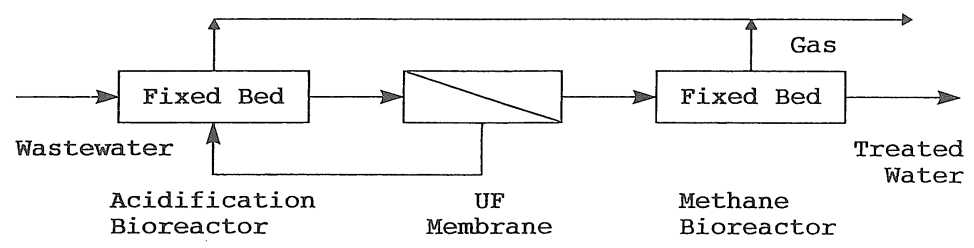

Fig. 1 Process flow diagram

ブラックボックスとして扱われてきた発酵槽内の細 菌の構成および活性度を知るために，細菌の MPN 計 数やバイアルびんによる代謝活性測定が行われてい る $^{2), 3)}$ 。二相式メタン発酵法の細菌群の挙動については ラボスケール装置での研究が実施されているが，パイ ロットスケール以上での実廃水処理の研究は少ない。 そこで，本研究では分離膜を複合化したパイロットス ケールの固定床型二相式メタン発酵法である「二相式 嫌気性メンブレンバイオリアクター」における両槽の 細菌の構成および活性について調査した。

本研究では，Fig.1 に示す酸発酵槽メタン発酵槽の 中間に分離膜を複合化させたプロセスを採用し，有機 性固形物を含有する大豆タンパク加工実廃水 (BOD 約 $1,000 \mathrm{mg} \cdot l^{-1}, \mathrm{SS}$ 約 $\left.700 \mathrm{mg} \cdot l^{-1}\right)$ を処理するフィール ドテスト (バイオリアクター有効容積 $3 \mathrm{~m}^{3}$ )を行った。 両槽のリアクターには微生物付着用担体として不織布 を用いた。パイロットプラントを用いた連続処理試験 については,SS の可溶化およびガス化が高効率で行え ること，固形物基質の分解よりみた二相分離特性が顕 著なこと,さらに酸発酵とメタン発酵の両槽よりメ夕 ンが生成されることを報告した ${ }^{4), 5) 。 ~}$

本論文では，この二相式嫌気性メンブレンバイオリ アクターにおける細菌群の特徴を把握するために，酸 発酵槽とメタン発酵槽の担体付着細菌についてバイア ルテストを行い，細菌の各種単一基質に対するメタン 生成比活性およびその比活性に及ぼす $\mathrm{pH}$ の影響につ いて検討した。また担体付着細菌に対して，メタン生 成細菌の補酵素である $\mathrm{F}_{420}$ を測定した。これらの結果 から SS 閉鎖系である分離膜複合化酸発酵槽および膜 透過水を受容しているメタン発酵槽において生育する 細菌について二，三の知見を得たので報告する。

\section{2. 実験方法}

\section{1 担体付着細菌}

全水理学的滞留時間は $18.6 \mathrm{~h}$ (酸発酵槽 $6.2 \mathrm{~h}$, メタン 発酵槽 $12.4 \mathrm{~h}$ )，全 COD 負荷は $1.82 \mathrm{~kg} \cdot \mathrm{m}^{-3} \cdot \mathrm{d}^{-1}$ (酸発 酵槽のみの $\mathrm{COD}$ 負荷は $\left.5.46 \mathrm{~kg} \cdot \mathrm{m}^{-3} \cdot \mathrm{d}^{-1}\right)$ の条件 ${ }^{5)}$ の連続処理試験終了後, 二相式嫌気性メンブレンバイ オリアクターの酸発酵槽とメタン発酵槽より担体付着
細菌を嫌気状態で採取し，担体付着細菌についてバイ アルテストを実施した。

\section{2 バイアルテスト}

バイアルテストは J. Dolfing らの方法3)を改良し， 以下に示す方法を用いて実施した。

1）基質溶液 (TOC 濃度 $\left.2 \mathrm{~g} \cdot l^{-1}\right) 20 \mathrm{~m} l$ と Table $\mathbb{1} に$ 示す無機塩溶液 $20 \mathrm{~m} l$ に，遠心分離 (約 $12,000 \mathrm{G}, 10$ 分 間）した担体付着細菌を湿潤状態で $10 \mathrm{~g}$ 科量し，内容 $130 \mathrm{~m} l$ のバイアル瓶に入れ混合する。

2） $12 \mathrm{~N}$ の水酸化ナトリウム溶液を用い, $\mathrm{pH}$ 計で測 定しながら初期 $\mathrm{pH}$ を約 $7.5 に$ 調整し,脱気した純水に て全量を $100 \mathrm{~m} l$ にし窒素パージ後密栓をした。

3 ) バイアル瓶を $30^{\circ} \mathrm{C}$ の恒温振盪培養器に入れ, 圧力 トランスデューサを用いた微小圧力計(鈴木製作所製, 最小圧力検出限界 $\left.10 \mathrm{mmH}_{2} \mathrm{O}\right)$ を用いて,バイアル瓶の 圧力上昇を連続的に測定記録した。

4 ）一定時間後にヘッドスペースのガス組成をガスク ロマトグラフにより分析測定した。またバイアル瓶中 の細菌量および残存基質濃度を求めるために MLSS，MLVSS，DOC（溶解性 TOC）を分析した。 5 ) ガス発生がほぼ直線的に観察された時間範囲につ いてガス生成速度を求め，バイアル瓶内の液体へのガ ス溶解分を補正した。ガスクロマトグラフで分析した メタン濃度より 1 日当りのメタン生成量を算出した。 またバイアル瓶内の MLVSSよりメタン生成比活性 を計算した。

供試細菌として酸発酵槽およびメタン発酵槽から嫌 気状態でサンプリングした担体付着細菌を用いた。 2

Table 1 Composition of inorganic chemicals

\begin{tabular}{|c|c|c|}
\hline $\mathrm{NaHCO}_{3}$ & 10.0 & $g \cdot l^{-1}$ \\
\hline $\mathrm{NH}_{4} \mathrm{Cl}$ & 0.5 & $g \cdot \ell^{-1}$ \\
\hline $\mathrm{K}_{2} \mathrm{HPO}_{4} \cdot 3 \mathrm{H}_{2} \mathrm{O}$ & 0.4 & $g \cdot \ell^{-1}$ \\
\hline $\mathrm{KH}_{2} \mathrm{PO}_{4}$ & 0.4 & $g \cdot \ell^{-1}$ \\
\hline $\mathrm{Na}_{2} \mathrm{~S} \cdot 9 \mathrm{H}_{2} \mathrm{O}$ & 0.25 & $g \cdot l^{-1}$ \\
\hline
\end{tabular}


種の細菌に対して，ギ酸，酢酸，プロピオン酸，酪酸， メタノール，エタノールの 6 種類の基質を用いて，基 質分解特性を調査した。また $\mathrm{pH}$ の影響を検討する際 にはリン酸緩衝液，炭酸水素ナトリウムを用いた。

\section{3 補酵素 $F_{420}$ 分析方法}

補酵素 $\mathrm{F}_{420}$ の定量方法は，以下に示す J. Dolfing ら の方法3を参考にした。

1) 試料 $2 \mathrm{~m} l$ と $10 \mathrm{mM}$ グリシン $+5 \mathrm{mMMg}$ -EDTA 混合溶液 $(\mathrm{pH} 7) 8 \mathrm{~m} l$ を試験管に加えよ く混合する。

2 ）沸騰水中にて試験管を14分間煮沸した後，氷を用 いて急冷させ，室温にする。

3 ) 遠心分離 (約 $12,000 \mathrm{G})$ を10分間行った後，清澄液 $5 \mathrm{~m} l$ を分取し,イソプロピルアルコール $10 \mathrm{~m} l$ と混 合する。

4 ）再度遠心分離 (約 $12,000 G)$ を10分間行った後，清

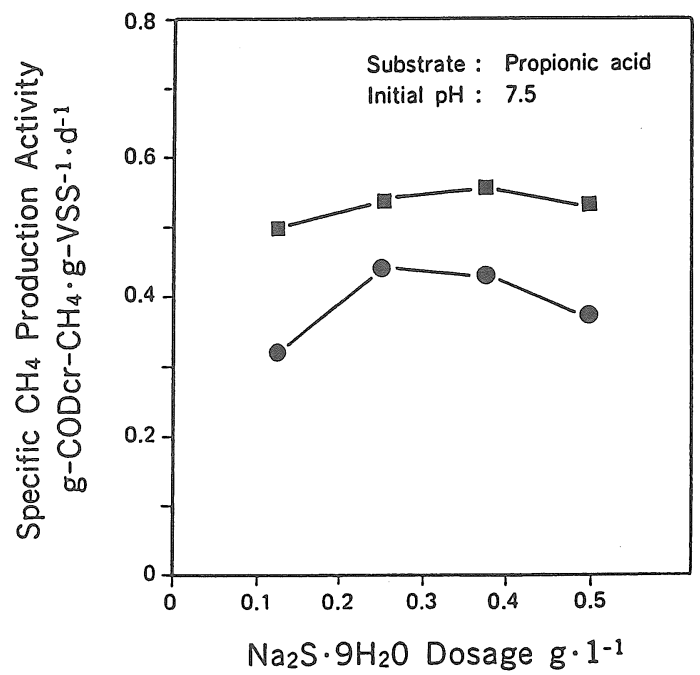

Fig. 2 Relationship between $\mathrm{Na}_{2} \mathrm{~S}$ Conc. and specific $\mathrm{CH}_{4}$ production activity

(O): Acidification Bioreactor, : Methane Bioreactor)
澄液の $\mathrm{pH}$ が8.8近傍であることを確認する。大きく 異なる場合は $\mathrm{KOH}$ にて調整する。

5 ) 直ちに, 分光光度計にて $420 \mathrm{~nm}$ の波長で励起さ せ， $470 \mathrm{~nm}$ の波長で放射される蛍光強度を測定す る。

\section{4 分析項目}

水質分析として TOC は島津製作所 TOC-500，SS (JISKO102)，揮発性脂肪酸 (液体クロマトグラフィ), $\operatorname{MLVSS}$ (下水試験法), 補酵素 $\mathrm{F}_{420}$ 蛍光強度 (分光蛍 光光度計)，この他に走査型電子顕微鏡 (SEM) による 観察を行った。ガス分析は， $\mathrm{CH}_{4}, \mathrm{CO}_{2}, \mathrm{~N}_{2}$ をガスク ロマトグラフィにより測定した。

\section{3. 実験結果および考察}

\section{1 バイアルテスト方法の検討}

Table 1 の無機塩溶液組成には硫化ナトリウムを加 えているが J. Dolfing らの方法3)では硫化ナトリウム は添加されていない。硫化ナトリウムを添加しない方 法ではバイアル瓶中の ORP (酸化還元電位) はメタン 生成がなされる範囲に到達していないため, 硫化ナト リウムの添加量を検討した。その結果, Fig. 2 亿示すよ うに，酸発酵槽およびメタン発酵槽からの担体付着細 菌を用いても，どちらの細菌ともに高いメタン生成比 活性を示した $\mathrm{Na}_{2} \mathrm{~S} ・ 9 \mathrm{H}_{2} \mathrm{O}$ 添加量 $250 \mathrm{mg} \cdot l^{-1}$ を採用し

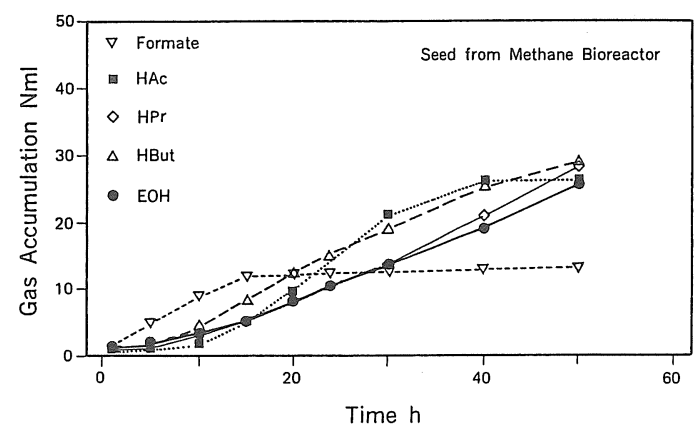

Fig. 3 Gas accumulation as a function of time

Table 2 Specific $\mathrm{CH}_{4}$ production activities

\begin{tabular}{|llllllll|}
\hline Test substrate & HFor & HAc & HPr & HBut & MOH & EOH & Blank \\
\hline $\begin{array}{c}\text { Acidification } \\
\text { Bioreactor } \\
\begin{array}{c}\text { Methane } \\
\text { Bioreactor }\end{array}\end{array}$ & 0.79 & 0.47 & 0.46 & 0.66 & 0.01 & 1.30 & 0.01 \\
\hline
\end{tabular}

HFor:Formate, HAc:Acetate, HPr:Propionate, HBut:Butyrate, MOH:Methanol, EOH : Ethanol 
バイアルテストを行った。

\section{2 メタン生成細菌のバイアルテスト}

バイアルテストでは基質を添加しないブランクのほ かにギ酸，酶酸，プロピオン酸，酪酸，メタノール， エタノールを基質として添加したが，ブランクおよび メタノール基質の場合はガス発生が認められなかっ た。ガス発生が認められたケースについて，発生ガス 積算量の経時変化についてメタン発酵槽の付着細菌の 場合を Fig. 3 に示した。図中，ギ酸基質の場合を除い てほぼ直線的にガス発生が観察された。ギ酸基質の場 合は, ギ酸の分解と共にバイアル瓶内の $\mathrm{pH}$ が 9.0 まで 上昇し，メタン生成の至適 $\mathrm{pH}$ 範囲を外れたためガス 発生の停滞を示したと考えられる。

Table 2 は酸発酵槽, メタン発酵槽より採取した担 体付着細菌についての pH7.5におけるメタン生成比 活性の比較結果を示している。メタン生成比活性は, 原田らの文献值 ${ }^{6}$, , ) と比較するためにメタンの完全酸 化に必要な酸素量 $\mathrm{g}-\mathrm{COD}-\mathrm{CH}_{4} \cdot \mathrm{g}-\mathrm{VSS}^{-1} \cdot \mathrm{d}^{-1}$ (= $\left.\mathrm{Nm} l-\mathrm{CH}_{4} \cdot \mathrm{g}-\mathrm{VSS}^{-1} \cdot \mathrm{d}^{-1} \times 0.002857\right)$ で表した。充媜 容積基準の酸発酵槽 VSS 濃度とメタン発酵槽 VSS 濃度は, 各々 $20.4,17.9 \mathrm{~g} \cdot l^{-1}$ とほほ同じ濃度であった。 酸発酵槽の VSS 中には，メ夕ン発酵細菌以外に大豆 タンパク SS の可溶化や酸発酵を担う細菌がより多く 含まれており，また，酸発酵およびメタン発酵の各槽 の $\mathrm{pH}$ は6.0および7.5に制御したが，バイアルテスト は $\mathrm{pH} 7.5$ で行ったため, 各種基質に対するバイアルテ

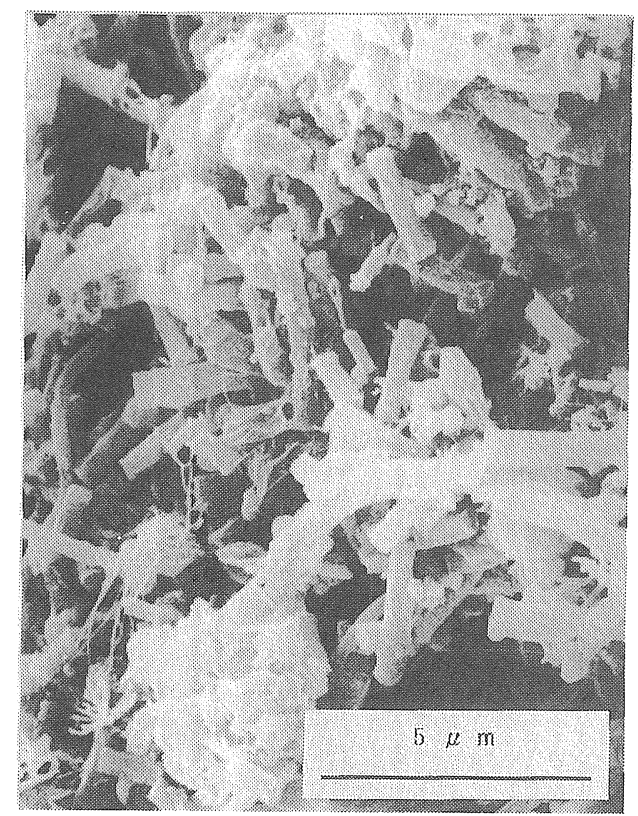

Fig. 4 SEM of microbes in Methane Bioreactor
ストにて酸発酵槽の細菌がメタン発酵槽の細菌よりお おむね低いメタン生成比活性を示したものと考えられ る。

ギ酸を基質としたバイアルテスト結果について，酸 発酵槽とメ夕ン発酵槽の細菌は各々 $0.79,1.63 \mathrm{~g}-\mathrm{COD}$ $-\mathrm{CH}_{4} \bullet \mathrm{g}-\mathrm{VSS}^{-1} \bullet \mathrm{d}^{-1}$ と他の基質に較べて高い值を示し ており, 両槽に水素資化性メタン生成細菌が高い比率 で存在していることが推定される。とくにメタン発酵 槽においてギ酸は最大の比活性を示しており, 酸発酵 槽の場合の 2 倍である。Dolfing らの報告3)では，水素 資化性メタン生成細菌のメタン生成比活性は酶酸資化 メタン生成細菌の約10倍の值を示しているため, 細菌 単位重量から見ると酶酸資化性メタン生成細菌の10分 の 1 の水素資化性メタン生成細菌が，同量のメタンを 生成することとなる。したがって，水素資化性メタン 生成細菌が検鏡観察では支配的になっていないと考え られる。

酶酸基質の比活性は,メタン発酵槽内の細菌が 0.95 , 酸発醳槽の場合 $0.47 \mathrm{~g} \mathrm{COD}-\mathrm{CH}_{4} \cdot \mathrm{g}-\mathrm{VSS}^{-1} \bullet \mathrm{d}^{-1}$ でメ タン発酵槽内の細菌の比活性は約 2 倍であった。酸発 酵槽の細菌の酢酸に対する比活性は，プロピオン酵と 同等で低い部類に属し，一方メタン発酵槽の細菌は高 い比活性の部類に入る。これは,メタン発酔槽へは主 に酢酸を含む有機混合水が流入しているためと考えら れる。Methanosarcina 属や Methanothrix 属は酶酸か らメタンを生成するが，Fig.4 に示すようにメタン発

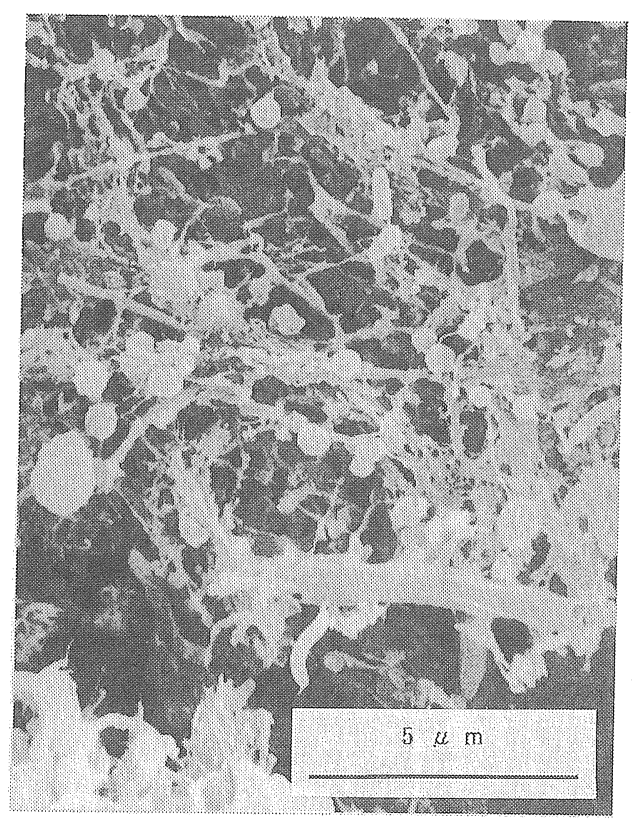

Fig. 5 SEM of microbes in Acidification Bioreactor 
Table 3 Specific $\mathrm{CH}_{4}$ production activities of bacteria grown in various anaerobic wastewaters and substrates

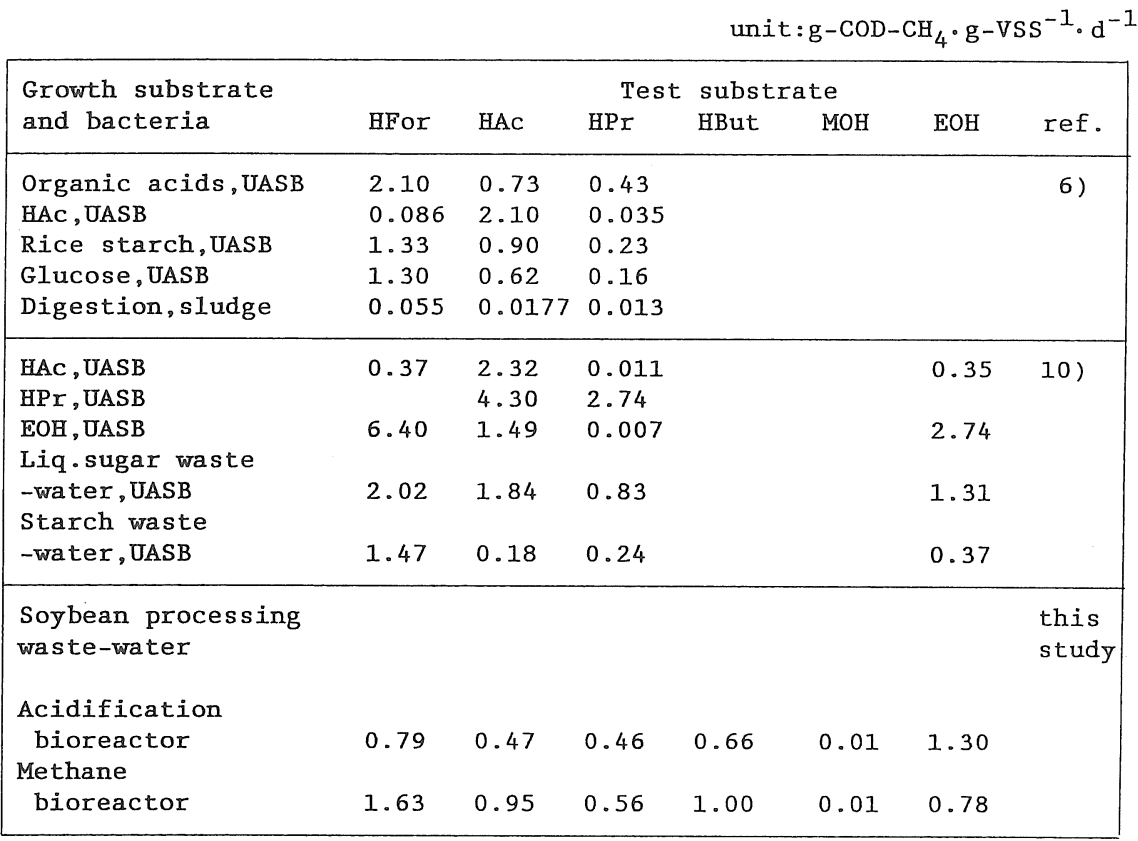

HFor:Formate, HAc:Acetate, HPr:Propionate, HBut:Butyrate, MOH:Methanol, EOH: Ethanol

酵槽内では多くの Methanothrix 属と思われる細菌が 観察されたが，酸発酵槽内では Fig.5 に示すように球 菌，桿菌等が支配的で Methanothrix 属は少なかった。 メタン発酵槽の細菌はギ酸に対して高い比活性を示し たが検鏡的には Methanothrix 属と考えられる細菌が 多く観察された。このことについて松本らは嫌気性流 動床の観察でMethanothrix 属と思われる細菌が多 かったが，MPN 法分析をしたところ実際は水素資化 性メタン生成細菌の数が最も多く，酢酸資化性メタン 生成細菌の数は最も少なかったと報告している ${ }^{8)}$ 。

プロピオン酸基質に対する比活性は $0.46,0.56 \mathrm{COD}$ $-\mathrm{CH}_{4} \cdot \mathrm{g}-\mathrm{VSS}^{-1} \cdot \mathrm{d}^{-1}$ と他の基質に較べ最も低い值を示 した。両槽の細菌の比活性の比較ではメタン発酵槽内 の細菌が1.2倍の值を示し共生細菌の存在, 水素分圧等 の環境条件がメタン発酵槽が酸発酵槽のそれよりやや 好適な状況にあったことを示しているが，プロピオン 酸の比活性は最も低いため反応律速となることが容易 に考えられる。連続処理試験結果において，メタン発 酵槽処理水中に平均 $7 \mathrm{mg} \cdot l^{-1}$ のプロピオン酸が検出 されたのも低い比活性によるものと考えられる。

酪酸に対するメタン生成比活性は酸発酵およびメ夕 ン発酵槽の細菌について各々0.66，1.00g $\mathrm{COD}^{-\mathrm{CH}_{4}}$ •
$\mathrm{g}-\mathrm{VSS}^{-1} \cdot \mathrm{d}^{-1}$ でメタン発酵槽の細菌の比活性が1.5倍 となった。メタン発酵槽の細菌の他の基質に対する比 活性を比較すると酪酸は比活性が高く，その結果メ夕 ン発酵槽処理水中には酪酸は認められなかった。

メタノールについては，酸発酵槽およびメタン発酵 槽のいずれの細菌もメ夕ノールに対して反応を示さな かつた。

エタノール基質のバイアルテスト結果は，酸発酵槽 の細菌が極めて高いメタン生成比活性を示した。酸発 酵槽およびメタン発酵槽の細菌の比活性は各々 1.30 , $0.78 \mathrm{~g} \mathrm{COD}^{-\mathrm{CH}_{4}} \cdot \mathrm{g}-\mathrm{VSS}^{-1} \cdot \mathrm{d}^{-1}$ で酸発酵槽の細菌が メタン発酵槽の細菌の1.7倍となった。酸発酵槽の細菌 はエタノール以外のすべての基質に対してメタン発酵 槽の細菌より常に低い值を示しているが，エタノール に対してのみ高い比活性を示した。エタノール分解は 共生反応により進行するため, 水素分圧の条件が、 $3 \times$ $10^{-1} \sim 10^{-6} \mathrm{~atm}$ の範囲で9),10)プロピオン酸, 酪酸の場合 より条件が緩いためと考えられる。

連続処理試験結果から全メタン生成量は酸発酵槽よ り $73 \%$ ，メタン発酵槽より $27 \%$ 割合になっており酸 発酵槽より生成するメタンが多い5)。バイアルテスト 結果および連続処理試験結果より考察すると，エ夕 
ノールからメタン生成に関与する共生細菌が好適環境 条件下で酸発酵槽内で活躍しメタン生成に大きく寄与 しているものと推定される。後述するようにデンプン 工場や製糖工場の UASB 処理におけるグラニュール と比較して, 酸発酵槽の細菌は, 高いエタノールのメ タン生成比活性を示した ${ }^{11)}$ 。各種基質に対するバイア ルテストにて酸発酵槽の細菌がメタン発酵槽の細菌よ りお打む称いメタン生成比活性を示した点を考慮す ると，エタノールについて極めて高いメタン生成比活 性を持ち，共生関係が形成されていたと思われる。

以上のような単一基質に対するバイアルテスト結果 をまとめると，ギ酸，プロピオン酸，酪酸，エタノー 儿等の水素を生成する反応において水素資化性メタン 生成細菌の共生が酸発酵槽およびメタン発酵槽内に認 められた。水素分圧の要求範囲が最も厳しいプロピオ ン酸は両槽の細菌とも他の基質に比較して最も低い比 活性を示した。酢酸の比活性はメタン発酵槽で高く槽 内には Methanothrix 属と思われる細菌が多く存在し ていた。エタノールの比活性は酸発酵槽の細菌で顕著 な值を示した。プロセス全体の約 $3 / 4$ を占める酸発酵槽 からのメタン生成はタンパク質・アミノ酸・エタノー ル分解径路が大きく寄与していると推定された。

バイアルテストで得られたメタン生成比活性を文献 上で報告されている消化污泥，人工基質で培養した UASB，実排水の UASB 菌吕,11) と比較して Table 3 に 示した。本バイオリアクターの細菌は消化污泥に対し て一桁以上の高い比活性を示した。本メタン発酵槽の 細菌は，デンプン工場の実排水のUASB 菌に対しギ 酸, 酢酸, プロピオン酸基質について, より高い比活 性を示した。また,ショ糖培養, 製糖工場排水の UASB 菌に対してもギ酸, 酢酸, プロピオン酸, エタノール 基質について，一部を除いて高い比活性を示した。さ

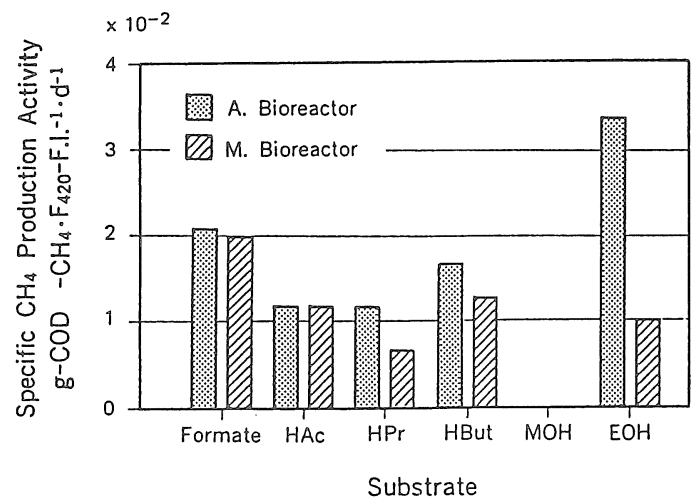

Fig. 6 Specific $\mathrm{CH}_{4}$ production activity on a basis of F.I.
らに有機酸培養 UASB 菌と比較すると，ギ酸，酢酸， プロピオン酸の基質に対してほぼ同様の比活性を有し ていることがわかった。これは,メタン発酵槽に膜透 過水である有機酸混合水が流入するためであり，また 不織布担体に UASB 菌と同様な共生関係を有する細 菌が固定されているためと考えられる。

本酸発酵槽の細菌の比活性はUASB 菌と比較する とその值は低いが，酢酸，プロピオン酸基質について は一部のUASB 菌より高い值を示している。エタノー ル基質に対して，最も高い值を示す製糖工場廃水 UASB 菌と同等である。本酸発酵のように SS が高濃 度に存在する槽においてもUASB 菌と同様の比活性 を一部において示しているのはメタン発酵槽と同様に 担体に好適環境条件下で多様な細菌が固定化されてい るためと考えられる。

\section{3 補酵素 $\mathrm{F}_{420}$ 基準のメタン生成比活性}

メタン細菌のエネルギー代謝系には，メタン細菌特 有の電子伝達物質が存在し，メタン生成反応に中心的 役割を果たしており，その中のひとつの補酵素 $\mathrm{F}_{420}$ を 定量化することにより,メタン細菌の活性を推察する ことが可能であるといわれている ${ }^{12)}$ 。各槽における担 体付着細菌の $\mathrm{g}-\mathrm{VSS}$ 当りの補酵素 $\mathrm{F}_{420}$ 蛍光強度（F. I.) は，酸発酵槽では $38 \mathrm{~F}_{420} \mathrm{~F} . \mathrm{I} \cdot$ ・g $-\mathrm{VSS}^{-1}$ ，メタン発酵 槽では $80 \mathrm{~F}_{420} \mathrm{~F} . \mathrm{I} . \cdot \mathrm{g}-\mathrm{VSS}^{-1}$ でメタン発酵槽の細菌は酸 発酵槽の細菌の2.1倍の值を示した。

酸発酵槽およびメタン発酵槽の細菌の $\mathrm{F}_{420}$ の蛍光 強度あたりのメタン生成比活性を Fig. 6 に示した。こ の結果より両槽の細菌の $\mathrm{F}_{420}$ 基準の比活性はギ酸，酢 酸についてはほほ同等の値を示した。Dolfing らは水

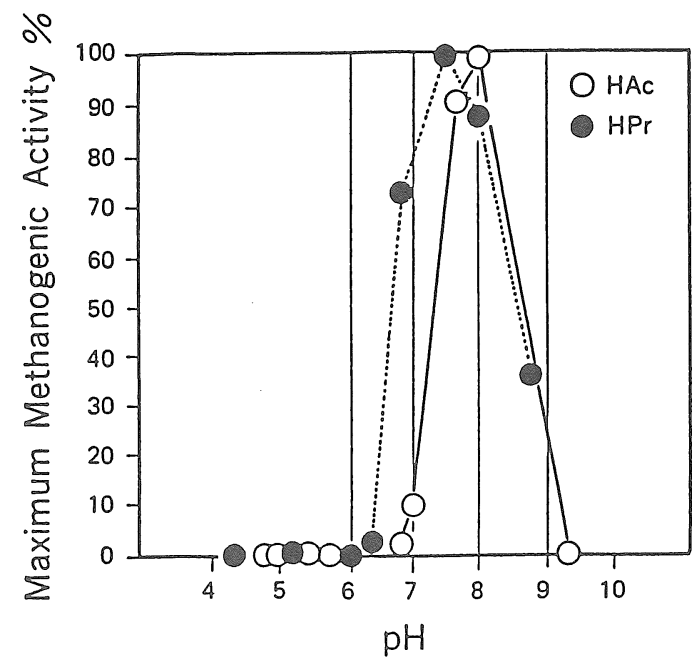

Fig. 7 Relationship between $\mathrm{pH}$ and methanogenic activity 
素資化性メタン生成細菌の $\mathrm{F}_{420}$ 含有率は高く酢酸資 化性メタン生成細菌の $F_{420}$ 含有率は一桁低いこと，ま たメタン生成比活性と $\mathrm{F}_{420}$ の関係について，相関関係 が成立する基質はギ酸のみであり，使用した他の基質 である酢酸, プロピオン酸, エタノールについては明 確な相関関係を見い出せなかったと報告している ${ }^{13)}$ 。 本バイアルテストのギ酸基質の結果は，Dolfing らの 結果と同様に酸発酵槽扔よびメタン発酵槽内メタン生 成比活性が同等であり，相関性があることを示した。 しかし，明確な相関関係がないと指摘された酶酸につ いて，本バイアルテスト結果では $\mathrm{F}_{420}$ 基準の比活性は ほぼ同等の值を示した。このような相関関係が得られ た理由として酸発酵槽およびメタン発酵槽は，分離膜 により区別けされているが，両槽とも同じ有機酸の混 合水からメタン生成を行っていることと，酶酸はメ夕 ン生成細菌が直接メタンへ転換できる基質であるため と考えられる。その他の基質，プロピオン酸，酪酸， エタノールについては, 両槽のメタン生成比活性と $\mathrm{F}_{420}$ には相関関係がないと判断される。

\section{4 メタン生成比活性に及ぼす pH の影響}

メタン発酵槽の担体付着細菌を用い, 酢酸ならびに プロピオン酸を基質としてメタン生成比活性に及ぼす $\mathrm{pH}$ の影響を検討した。Fig.7 亿示すように最大比活 性は，酢酸基質の場合 $\mathrm{pH} 8.0$ 近傍に，プロピオン酸基 質の場合 $\mathrm{pH} 7.5$ 近傍に認められた。全体的には $\mathrm{pH} 7$ 〜8に扔いて高い比活性を示したが, $\mathrm{pH}$ が 6 以下，あ るいは 9 以上においては活性は認められなかった。Zehnder らの文献によるとメタン生成細菌の属種の違い により至適 $\mathrm{pH}$ は $6 \sim 8$ の比較的狭い範囲に存在して いる ${ }^{14)}$ 。一般にメタン発酵による排水処理において重 要な役割を担っている Methanothrix 属の至適 $\mathrm{pH}$ は 7.6近傍に存在している。また Dolfing らはUASB の グラニュールを用いた場合, 酢酸基質で $\mathrm{pH} 7.1$ ，プロ ピオン酸基質で $\mathrm{pH} 7.6$ 亿最大メタン生成比活性が発 現することを示している ${ }^{3)}$ 。本実験ではメタン発酵槽 の $\mathrm{pH}$ を7.5に制御し Methanothrix 属のメタン生成細 菌を高度に集積することを図った。Fig.4亿示す走査 型電子顕微鏡写真の観察結果およびバイアルテストに よる至適 $\mathrm{pH}$ の検討結果より，固定床担体に高活性な メタン生成細菌を高濃度に固定化できたことが確認さ れた。

\section{4.まとぬ}

パイロットプラントスケールの固定床型酸発酵槽と メタン発酵槽の間に分離膜を設置した二相式嫌気性メ ンブレンバイオリアクターの担体に付着しているメタ ン生成細菌の比活性をバイアルテストにより調査し
た。この連続フィールドテストは大豆タンパク加工廃 水を使用して実施したものである。その結果, SS 閉鎖 系となった分離膜複合化酸発酵槽と膜透過水を受容す るメタン発酵槽の各々を生育しているメタン生成細菌 について次の知見を得た。

1) ギ酸，プロピオン酸，酪酸およびエタノールの 単一基質に対するメタン生成比活性は，両槽とも共生 関係によりメタン生成が行われていることを示唆し た。各基質の主要なテスト結果については，プロピオ ン酸に対する比活性は，両槽とも低くプロピオン酸分 解が律速となることが示唆された。ギ酸に対する比活 性は，両槽とも高く，とくにメタン発酵槽においては 6 基質中最大の值を示した。エタノールに対してはと くに酸発酵槽の細菌が極めて高い活性を示した。酸発 酵槽ではタンパク質・アミノ酸からエタノール・メ夕 ンの分解経路を担う細菌が主体を占めると推定され た。一方メタン発酵槽の細菌は, プロピオン酸, メ夕 ノールを除きいずれの基質に対しても比較的高い比活 性を示した。

2 ) 酸発酵槽とメタン発酵槽の補酵素 $\mathrm{F}_{420}$ 基準の メタン生成比活性はギ酸および酢酸に対して両槽とも ほぼ同じ值を示した。

3 ) メタン発酵槽の細菌の至適 $\mathrm{pH}$ については $\mathrm{pH}$ 7 ～ 8 の狭い範囲において最大の活性を示した。

4 ) 実廃水を使用した UASB 菌の文献值と比較す ると，ギ酸，酶酸については，ほほ同等の比活性を示 し，エタノールに対する比活性は本バイアルテスト結 果の方が高い值を示した。本テストでは比較的低い值 を示したプロピオン酸に対する比活性はUASB 菌と 比較すると高い比活性を示した。このように，分離膜 を複合化した二相式プロセスの固定床担体には，多様 な細菌が好適な環境条件下で固定化され，UASB グラ ニュールと同等あるいはそれ以上のメタン生成比活性 を有するメタン生成細菌が生存していることが判明し た。

\section{謝 辞}

本研究は，通産省工業技術院大型プロジェクト「水 総合再生利用システムの研究開発」の一環として, NEDO からの委託によりアクアルネサンス技術研究 組合内にて実施されたものであり，関係者各位に対し て厚く御礼申し上げます。また本実験に尽力のあった 小山時彦，増原功，藤谷淳二の各氏に心謝します。

（原稿受付 1990年12月10日）

（原稿受理 1991年 8 月 1 日）

参 考 文 献

1) Novaes, R.F.V. (1986) Microbiology of anaerobic diges- 
tion, Water Science and Technology, 18, (12) 1-14.

2 ) 李玉友, 野池達也（1989）污泥の嫌気性消化における細菌群 の分布と物質分解特性一メタン生成菌とホモ酢酸生成菌を中 心として一，水質污濁研究，12，771-780。

3 ) Dolfing, J. and Bloemen, W. G.B.M. (1985) Activity measurements as a tool to characterize the microbial composition of methanogenic environments, Journal of $\mathrm{Mi}$ crobiological Methods 4, 1-12.

4 ) 油科嘉則, 長谷川潤, 佐藤広已（1991）分離膜複合化二相式 メ夕ン発酵のプロセス比較に関する研究，水質污濁研究，14, 312-321.

5 ) 油科嘉則, 長谷川潤（1991）嫌気性 2 相式メンブレンリアク 夕ーによる大豆蛋白加工排水処理一酸発酵槽・分離膜複合反応 系での可溶化・酸発酵に関する研究一, 水質污濁研究, 14 , 322-333.

6 ) 外村雅生, 原田秀樹, 桃井清至 (1988) UASB 反応器培養グ ラニュール生物のメタン生成活性と補酵素 $\mathrm{F}_{420}$ の関係, 土木学 会第 43 回年次学術講演会要旨集, 10 月。

7 ) 原田秀樹 (1989) 嫌気性処理に関する細菌群の研究現況一メ タン生成細菌一, 下水の嫌気性処理に関する調査, 建設省都市 局下水道部，社団法人土木学会，158.

8 ）松本明人，坂本勝，野池達也（1990）嫌気性流動床における
微生物膜の菌相に関する研究, 土木学会第 45 回年次学術講演会 要旨集, PS II-21, 42-43.

9) Harper, S.R. and Pohland, F.G. (1986) Recent developments in hydrogen management during anaerobic biological wastewater treatment, Biotechnology and Bioengineering, 28, 585-602.

10) McCarty, P.L. (1981) One hundred years of anaerobic treatment, 2nd International Conference on Anaerobic Digestion.

11) Stams, A.J.M. Grotenhuis, J.T.G. and Zehnder, A.J.B. (1989) Structure-function relationship in granular sludge, 5th International Symposium on Microbial Ecology, Kyoto. 12）磯田悟 (1988) メタン菌活性蛍光計測法, 用水と廃水, 30 (10) $9-13$.

13) Dolfing, J. and Mulder, J.W. (1985) Comparison of methane production rate and coenzyme $\mathrm{F}_{420}$ content of methanogenic consortia in anaerobic granular sludge, Applied and Environmental Microbiology, 49, 1142-1145.

14) Zehnder, A.J.B. Ingoorsen, K. and Marti, T. (1981) Microbilogy of methane bacteria, Anaerobic Digestion, Elsevier, $45-68$. 


\section{論 文 要 旨}

\section{二相式傔気性メンブレンリアクターにおけるメタン生成細菌の活性について}

油科 嘉則* 長谷川 潤*

* 千代田化工建設株式会社環境技術開発センター

〈水質污濁研究 Vol.14 No.12（1991） pp.859〜866〉

大豆タンパク加工排水を処理するパイロットスケールの固定床型酸発酵槽およびメタン発酵槽の間に分離膜 を設置した二相式嫌気性リアクターの各槽の担体に付着しているメタン生成細菌の活性を調査した。6 種類の 基質を使用したバイアルテストによりメタン生成比活性を求めた結果, SS 閉鎖系となる分離膜十酸発酵槽と膜 透過水を受容するメタン発酵槽の担体付着細菌について次のことがわかった。酸発酵槽の細菌は，ギ酸，酶酸， プロピオン酸, 酪酸よりもエタノール基質に対して高い比活性を示した。メタン発酵槽の細菌は, 文献の UASB グラニュールのバイアルテスト結果と比較して，同等かそれ以上の比活性を示した。本実験より，酸発酵槽か らのメタン生成はタンパク質，アミノ酸，エタノール分解経路が大きく寄与していること，メタン発酵槽のメ タン生成細菌は有機酸培養の UASB グラニュールと類似した共生関係を有する細菌群であることが考察され た。

\section{干潟底泥における脱窒量の測定法の比較}

伊藤 和男* 土山 秀樹* 山守 英朋* 浦野 久美子**

* 名古屋市公害研究所 * * 玉野総合コンサルタント

〈水質污濁研究 Vol.14 No.12（1991） pp.867〜875〉

アセチレン阻害法による底泥の脱窒活性の測定について，以下の 3 種の方法の比較検討を行った。

( I ) スラリー状の泥を $\mathrm{BOD}$ ふらんびんで培養生成した $\mathrm{N}_{2} \mathrm{O}$ 生成量, (II) 末攪乱の柱状コア試料をガラスカ ラムにつめ生成する $\mathrm{N}_{2} \mathrm{O}$ 量，(III) 野外においてガラス円筒で捕集された $\mathrm{N}_{2} \mathrm{O}$ 量，これら 3 種の測定值は， （ I ）：61〜 62，(II）：33〜39，(III）：47〜 $56 \mathrm{mgN}_{2} \cdot \mathrm{m}^{-2} \cdot \mathrm{d}^{-1}$ であった。スラリー状の泥の培養びん法による測定 值は，末攪乱試料の測定值の約 2 倍であった。

名古屋港河口域の柱状コア試料による $\mathrm{N}_{2} \mathrm{O}$ 生成量の垂直分布を，BOD ふらんびん培養法で測定した。

\section{川崎市における地下水中の低漂点有機塩絜化合物の調査結果}

吉川 サナエ* 山本 順昭* 櫻木 進* 横田 覚**

* 川崎市公害研究所 $* *$ 川崎市環境保全局公害部水質課

〈水質污濁研究 Vol.14 No.12（1991） pp.876〜882〉

トリクロロエチレン，テトラクロロエチレン等の低沸点有機塩素化合物による川崎市内の地下水污染の現況 